\title{
El Cine ¿puede hacernos mejores? ¿Puede contribuir al Bienestar y a la Salud?
}

\begin{abstract}
Lo digo con total convicción, el buen cine me enamora; recuerdo una frase que alguien dijo al salir de la presentación de una película: "otra vez lo mismo, sales del cine y el mundo sigue igual como lo dejaste al entrar". Evidentemente, nada cambia, sin embargo, durante un rato el cine que sabe de arte nos permite la ilusión de vivir otras historias ajenas a las nuestras, como escribe Fernando Pessoa en el Libro del Desasosiego: "el arte nos libera ilusoriamente de la sordidez de ser".
\end{abstract}

Mientras sentimos los males y las injurias de Hamlet, Príncipe de Dinamarca, no sentimos los nuestros... Por arte se entiende todo lo que nos deleita sin ser nuestro, el rastro de unos pasos, la sonrisa que a alguien regalamos, el ocaso, el poema... Poseer es perder, sentir sin poseer es guardar, porque es extraerle a una cosa su esencia.

En una sala de cine o en el salón de casa delante del video, inmersos en la ilusión de una obra de arte, nos enfrentamos a temas arduos que, unas veces, son auténticos laberintos sobre las cosas de la vida y, otras, son historias fantásticas que nos ayudan a desconectar de nuestros problemas o, simplemente, de nuestra vida cotidiana, por eso no estoy de acuerdo con Michael Haneke, director de La pianista, Caché y La cinta blanca, entre otras, cuando afirma que el cine interesante de hoy día viene, sólo, del tercer mundo, porque esa gente tiene algo por lo que luchar. Nosotros no hacemos más que describir permanentemente el asco que sentimos por nosotros mismos.

¿Cómo puede contribuir el cine a la comprensión de aspectos relacionados con la salud física y mental? La explicación puede venir, tal vez, porque el cine mantiene una estrecha y mutua relación con la filosofía, la religión, la ciencia, el derecho, la política, la economía, la medicina, la psicología, la sociología y el arte; en realidad, hay un vinculo entre el arte y la vida, entre el arte y la cultura en general, siempre se puede abrir un debate sobre qué se considera cultura, qué implica tener una cultura o formar parte de un grupo que ostenta una determinada cultura.

Dramas y comedias reflejan la vida misma, proporcionando la posibilidad de identificarnos con algunos de los personajes, también nos evocan recuerdos, nos ayudan a asociar con historias nuestras o de nuestros allegados, nos permiten salir de nuestra rutina para ver el mundo desde otra perspectiva $y$, además, nos introducen en el mundo de la metáfora por excelencia, que es el mundo que nos va a ayudar a conocernos y sentirnos mejor, porque nos trasmiten sentimientos y vivencias, y gracias a los sentimientos tomamos conciencia de que no somos otros, sino nosotros mismos. Los sentimientos nos otorgan nombre, y con ese nombre somos lo que somos.

A mi, personalmente, siempre me fascinaron las historias, los cuentos y los relatos, tanto escuchando como leyendo; junto con los libros, el séptimo arte es un buen invento para esto; se dice que Hemingway era quien escribía los mejores cuentos del mundo y es un dato curioso porque sus cuentos siempre dejan al lector con sobreentendidos y alusiones, parece que lo mejor de la historia es aquello que no se ha contado, seguramente lo no dicho, lo que se intuye y lo que sobrevuela en cada título, lo que no se acaba de entender totalmente, lo que estimula la duda, es lo más atractivo y lo más formativo.

El cine entretiene, informa y educa, gracias a la palabra aprendemos a vivir; ya la madre sostiene al bebé en sus brazos susurrándole palabras mezcladas con alimento; a través de dosis diarias de comida y palabras uno va creciendo y aprendiendo a escuchar historias hasta que llega el momento de contarlas; todos, niños y 
adultos, saben, cada uno a su manera, contar historias sobre sí mismos y sus experiencias, lo que ayudará a manejarse en la vida.

El cine estimula la mente porque permite un viaje a través del tiempo y del espacio. Desde aquel año 1895 en que los hermanos Lumiere presentaron la primera película titulada "La salida de los trabajadores de la fábrica Lumiere" se han producido muchas transformaciones sociales que se han ido reflejando en la pantalla. Actualmente estamos, de nuevo, en un período de grandes cambios, en la llamada sociedad posmoderna, de la globalización y del bienestar, donde a veces más que seguridad, encontramos dudas y perplejidades y el cine puede ser un buen medio para encontrar nuevas preguntas y algunas respuestas sobre estos cambios sociales. Cuando alguien me pregunta cual es la película que más me ha impactado o ha influido en mi vida personal o profesional, en principio, nunca sé que contestar, aunque siempre acabo encontrando alguna viñeta, diálogo, personaje o título que me ayudaron a manejarme en momentos difíciles y me hicieron sentir bien conmigo misma y con mi entorno.

Rosario Castaño Catalá Psicóloga especialista en Psicología Clínica, Psicoterapeuta, Sexóloga, Vocal del Instituto de Psicoterapia Relacional. Centro Médico Instituto Palacios. 